\title{
Deep stromal mycobacterial keratitis: viable bacteria after six months of treatment: case report and literature review
}

\author{
Ceratite estromal profunda por micobactéria:bactéria viá vel após seis meses de \\ tratamento:relatodecaso e revisãoda literatura
}

\author{
Filipe Accioly de Gusmão \\ Lênio Alvareng'a ${ }^{2}$ \\ Luciene Barbosa ${ }^{3}$ \\ Jorg'e Sampaio $^{4}$ \\ Sylvia Cardoso Leão 5 \\ Ana Luisa Hofling-Lima ${ }^{6}$ \\ Denise de Freitas
}

\begin{abstract}
To report the presence of viable mycobacteria in a patient with keratitis treated for 6 months. Species identification was performed using the PRA method (polymerase chain reaction followed by restriction endonuclease analysis). Clonality was evaluated with RAPD (randomly amplified polymorphic DNA) and ERIC-PCR (enterobacterial repetitive intergenic consensus - polymerase chain reaction) methods. The patient reported trauma due to a metallic foreign body 3 weeks prior to presentation. Initial corneal scraping cultures revealed Mycobacterium abscessus. After 6 months of topical and systemic treatment the patient presented with no active inflammation and was considered clinically cured. An optic penetrating keratoplasty was performed. Culture of the excised cornea revealed Mycobacterium abscessus. Both isolates had the same clonal origin. The most interesting finding of this case report was the positive culture of the excised cornea after 6 months of intensive specific topical therapy. To our knowledge, this is the first report in the literature showing this possibility in the treatment of Mycobacterial keratitis. Thus, Mycobacterium abscessus may present viable bacteria after long-term treatment and should be followed carefully for a long period of time after tapering the medication.
\end{abstract}

Keywords: Eye foreign bodies/complications; Keratitis/microbiology; Cornea/microbiology; Eye infections, bacterial/microbiology; Mycobacteria, atypical/isolation \& purification; Mycobacterium fortuitum/isolation \& purification; Mycobacterium chelonae/isolation \& purification; Case report

Trabalho realizado na Universidade Federal de São Paulo (UNIFESP). São Paulo (SP).

Médico Residente de Oftalmologia da Universidade Federal de São Paulo (UNIFESP). São Paulo (SP).

${ }^{2}$ Pós-Graduando do Setor de Córnea e Doenças Externas da UNIFESP. São Paulo (SP).

Chefe do Setor de Córnea e Doenças Externas da UNIFESP. São Paulo (SP).

${ }^{4}$ Médico do Laboratório Fleury. São Paulo (SP).

${ }_{5}^{5}$ Professora do Departamento de Microbiologia, Imunologia e Parasitologia da UNIFESP. São Paulo (SP) ${ }^{6}$ Chefe do Departamento de Oftalmologia da UNIFESP. São Paulo (SP).

Coordenadora Cientifica do Setor de Córnea e Doenças Externas da UNIFESP. São Paulo (SP).

Endereço para Correspondência: Filipe Accioly de Gusmão - R. Machado Bittencourt 220 - Apto. 92 - São Paulo (SP) CEP 04044-000

E-mail: figusmao@uol.com.br

Recebido para publicação em 23.04.2004

Versão revisada recebida em 24.02.2005

Aprovação em 06.05.2005

\section{INTRODUCTION}

\section{purification; Case report}

\section{ing}

Nontuberculous, or atypical mycobacteria (NTM) are known to cause infectious keratitis, most of them caused by two species: $M$. fortuitum and $M$. chelona $^{(1-2)}$. Commonly, it occurs after either accidental or surgical trauma ${ }^{(3)}$.

In 1965, Turner and Stinson ${ }^{(1)}$ described the first case of NTM keratitis in a corneal ulcer that developed 4 months after removal of a superficial corneal body; $M$. fortuitum was identified as the etiological agent. More recently, mycobacteria species were reported to cause infectious keratitis after LASIK, photorefractive keratectomy, and radial keratectomy ${ }^{(4-5)}$.

The purpose of this study is to describe a case of deep stromal mycobacterial keratitis in a 41-year-old patient that was considered cured after 6 months of clinical treatment and in reality, had viable microorganisms.

\section{CASE REPORT}

A 41-year-old male presented with blurred vision, hyperemia and pain in 
the right eye. He reported a trauma due to a metallic foreign body in the affected eye 3 weeks before. Biomicroscopy showed conjunctival hyperemia and deep stromal infiltrates with overlying epithelial defect (Figure 1). Left eye examination was unremarkable. Best corrected visual acuity (BCVA) was hand motion (OD) and 20/20 (OS). Corneal scrapings were obtained and cultures revealed Mycobacterium abscessus, identified by polymerase chain reaction followed by restriction endonuclease analysis. Drug susceptibility was analyzed through the Etest test. The minimal inhibitory concentrations demonstrated susceptibility to: amikacin $(12.0 \mu \mathrm{g} / \mathrm{ml})$, clarithromycin $(0.064 \mu \mathrm{g} / \mathrm{ml})$, and cefoxitin $(16 \mu \mathrm{g} / \mathrm{ml})$; and resistance

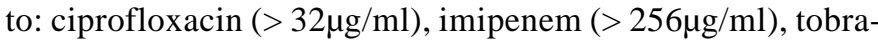
mycin $(12 \mu \mathrm{g} / \mathrm{ml})$, and doxycycline $(>32 \mu \mathrm{g} / \mathrm{ml})$.

A superficial keratectomy was performed and the patient was treated with topical $1 \%$ clarithromycin, $1.5 \%$ amikacin, $0.3 \%$ ofloxacin, and oral clarithromycin (500 mg 12/12h). Topical drops were administered every hour initially and then tapered to every two hours and then maintained at a dosage of every three hours for one month. After the first month the drugs were instilled four times daily. Oral prednisone was used to control initial inflammation (40 $\mathrm{mg}$ a day) and was subsequently tapered (Figure 2).

After 6 months of treatment, the patient was considered clinically cured (healed) and a penetrating keratoplasty (PK) with optical purposes was performed. Surprisingly, culture of the excised cornea revealed viable Mycobacterium abscessus. Analysis of clonality with randomly amplified polymorphic DNA $^{(6)}$ and ERIC-PCR (enterobacterial repetitive intergenic consensus - polymerase chain reaction) $)^{(7)}$ methods demonstrated that isolates had the same clonal origin (Figure 3 ).

Topical prednisolone and clarithromycin were maintained for 2 months. Ten months after the PK, BCVA was 20/40 with no signs of infection recrudescence.

\section{DISCUSSION}

NTM are opportunistic pathogens requiring some disturbance in the normal ocular environment to produce infection. NTM can cause infectious crystalline keratopathy ${ }^{(1)}$, and corneal infection is usually characterized by indolent course (relatively low virulence and slow rate of growth), and resistance to medical treatment ${ }^{(2-3)}$.

Patients' complaints are usually of moderate pain, photophobia and blurring vision. Clinical signs, which often develop within 2 to 8 weeks after inoculation reveal a paucity of inflammation and the formation of a sharply demarcated graywhite branching, round or needle-like opacities in the corneal stroma. This crystalline keratopathic changes are due to colonization of the organisms along the lamellar planes in the stroma. Ring infiltrates are common and may cause confusion with herpetic, fungal or Acanthamoeba keratitits. Intact overlying epithelium is sometimes observed and pain is variable, but is certainly never as excruciating as in Acanthamoeba

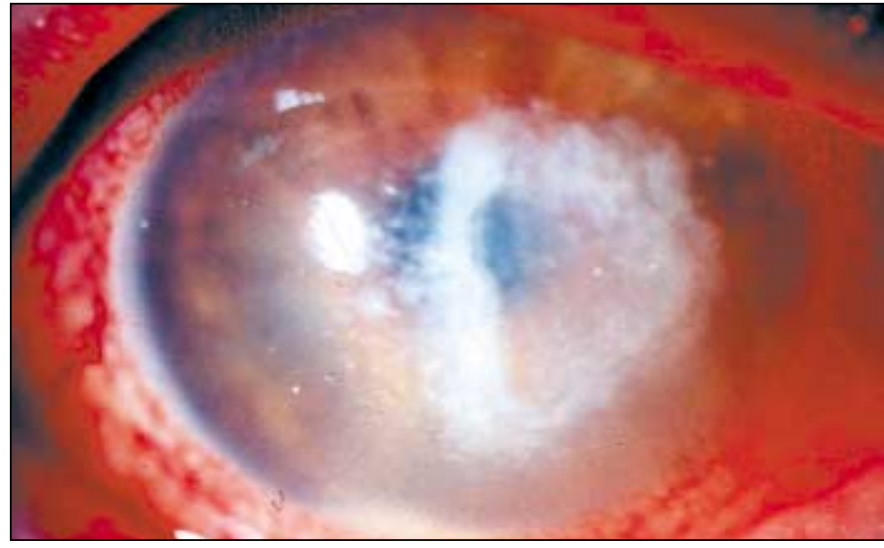

Figure 1 - Clinical photograph of the right eye. Biomicroscopy demons trating deep stromal infiltrates and hypopyon

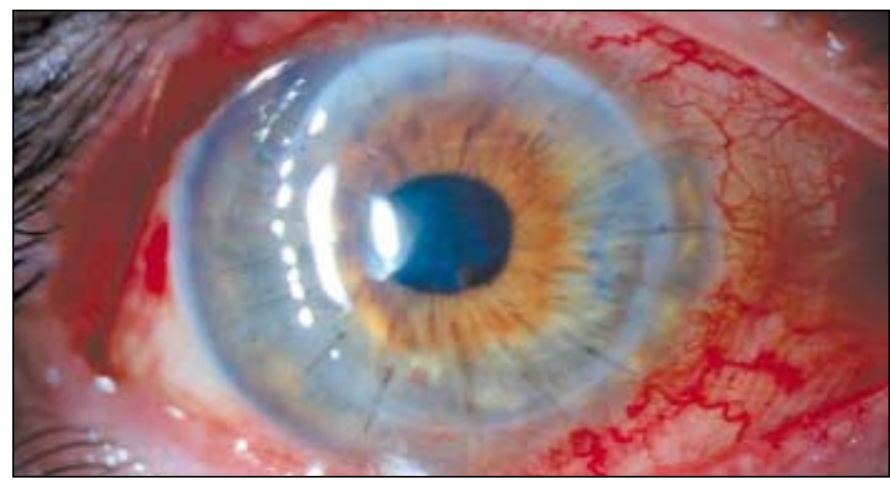

Figure 2 - One month after the PK for visual rehabilitation

keratitits $^{(4)}$. The degree of anterior chamber inflammation appears to parallel the gravity of the events in the cornea, and is probably a reactive rather than an infectious phenomenon ${ }^{(4)}$.

NTM can be isolated from a variety of environmental sites, including, water, soil, animals, and food, which are easily contaminated $^{(4)}$. Most species can survive nutritional deprivation, extreme temperature $\left(>45^{\circ} \mathrm{C}\right)$, and are resistant to the action of formaldehyde, glutaraldehyde, and other commonly used disinfectants. Positive nontuberculous mycobacterial cultures on Lowenstein-Jensen agar medium constituted a definitive diagnosis $\mathrm{s}^{(3-4)}$. Since these organisms are gram-positive and are infrequently isolated, they have at times, been mistakenly identified in smears as diptheroid or nocardial ${ }^{(3)}$ species. Restriction endonuclease analysis can be helpful in these cases, providing an accurate diagnosis ${ }^{(8)}$.

The majority of cases, have been associated with a previous history of either a foreign body trauma $^{(3)}$ (metal or vegetable material) or surgical trauma (radial keratotomy, penetrating keratoplasty, suture removal, surgical posterior capsulotomy, and even simply wear of contact lens) $)^{(2)}$. Unsatisfactory medical therapy, can be associated with a delayed diagnosis, slow response to therapy, inadequate drug penetration, resistance to most conventional antibiotics and the emergence of a resistant strain, especially when using monotherapy ${ }^{(3,5)}$. 


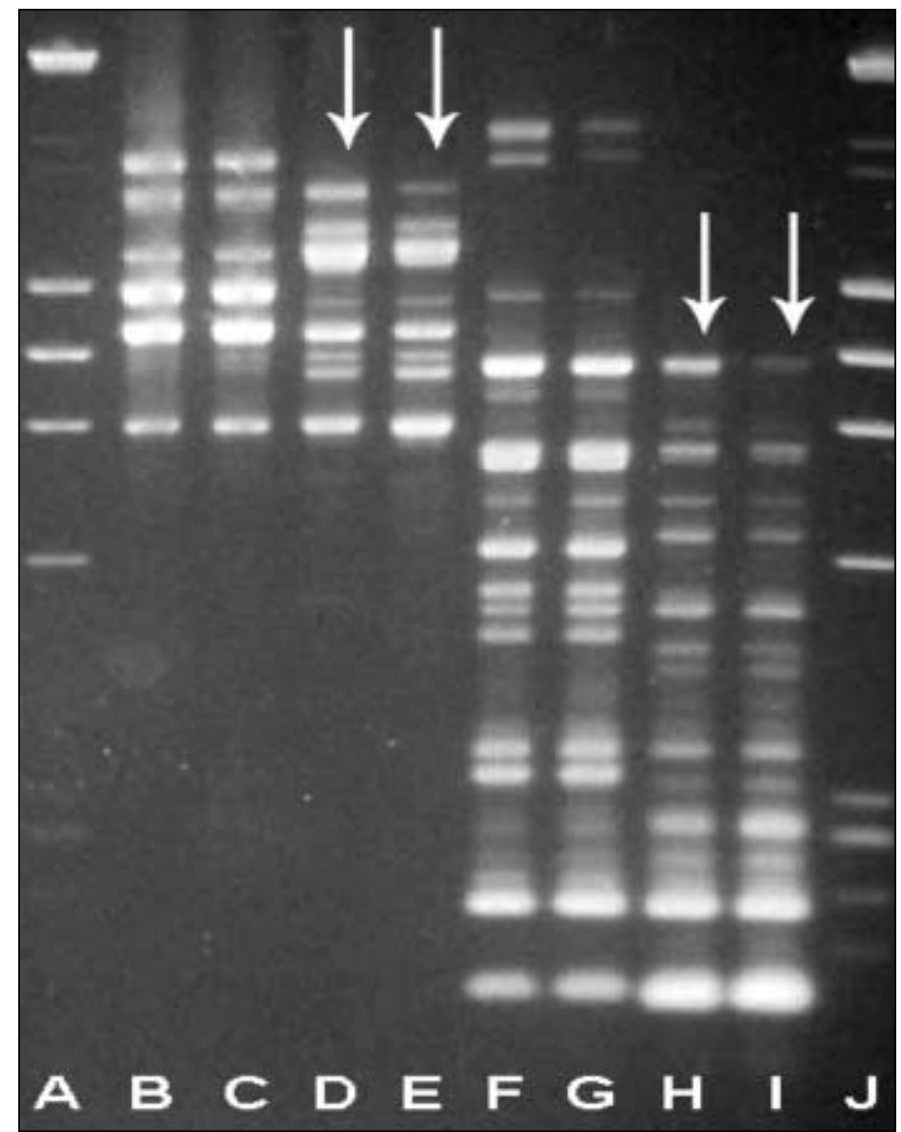

Figure 3 - Agarose gel electrophoresis of amplified DNA from clinical isolates of Mycobacterium abscessus, obtained by ERIC-PCR or RAPD-PCR methods. Lanes. A: DNA standards; B: RAPD-Control 1; C: RAPD-Control 2; D: RAPD - Patient initial isolate; E: RAPD - Patient isolate after 6 months of treatment; F: ERIC-Control 1; G: ERIC-Control 2; H: ERIC - Patient initial isolate; I) RAPD - Patient isolate after 6 months of treatment; J: DNA standards. Control 1 and 2 are clinical isolates known to present the same clonal origin. Arrows indicate the identical patterns of the two isolates from the patient in both methods

Keratitis caused by mycobacteria has proved to be difficult to treat. Aggressive long-term therapy with a combination of topical fortified antibiotics and sometimes oral medications is usually necessary to control the infection ${ }^{(3-4)}$, and although corticosteroid therapy results in transient improvement of the inflammation and scarring, it might contribute to failure of medical treatment and the chronicity of the disease ${ }^{(4)}$. In our case, we achieved good clinical results with the aforementioned medications and after 6 months our patient was considered clinically cured without signs of active infection/inflammation.

The most interesting finding of this report was the positive culture of the excised cornea after 6 months of intensive specific therapy which demonstrates that clinical cure may not correlate with sterility of scar tissue. To our knowledge, this is the first report in the literature showing this possibility in the treatment of mycobacterial keratitis.

Thus, Mycobacterium abscessus in deep stromal keratitis may be viable after long-term treatment. Finally, patients should be followed carefully for a long period after tapering the medication in order to clinical cure to be proved and patients undergoing PK should have a laboratory work-up of the excised cornea.

\section{RESUMO}

O objetivo do caso é descrever a presença de micobactérias viáveis em pacientes com ceratite, 6 meses após tratamento intensivo. A identificação de espécies, foi efetuada usando método PRA (polymerase chain reaction seguida pela restriction endonuclease analysis). Clonalidade foi avaliada pelos métodos RAPD (randomly amplified polymorphic DNA) e ERIC-PCR (enterobacterial repetitive intergenic consensus polymerase chain reaction). Paciente refere trauma com corpo estranho metálico há 3 semanas. A cultura da córnea revelou Mycobacterium abscessus. Após 6 meses de tratamento tópico e sistêmico, paciente apresentava-se sem inflamação, sendo considerado clinicamente curado. Realizou-se então, uma ceratoplastia penetrante com intuitos ópticos. A cultura da córnea transplantada revelou micobactérias de mesma origem clonal. $\mathrm{O}$ achado mais interessante neste relato, foi a positividade da cultura da córnea transplantada após 6 meses de intenso tratamento específico. Ao nosso conhecimento, esse é o primeiro caso relatado na literatura mostrando essa possibilidade em tratamento de ceratites por micobactérias. Assim, os pacientes com ceratite por Mycobacterium abscessus podem apresentar bactérias viáveis após longo tempo de tratamento específico e precisam ser seguidos cuidadosamente por um longo período de tempo.

Descritores: Corpos estranhos no olho/complicações; Ceratite/microbiologia; Córnea/microbiologia; Infecções oculares bacterianas/microbiologia; Micobactérias atípicas/isolamento \& purificação; Mycobacterium fortuitum/isolamento \& purificação; Mycobacterium chelonae/isolamento \& purificação; Relato de caso

\section{REFERENCES}

1. Hu FR, Luh KT. Topical ciprofloxacin for treating nontuberculous mycobacterial keratitis. Ophthalmology. 1998;105(2):269-72.

2. Hu Fr. Extensive lamellar keratectomy for treatment of nontuberculous mycobacterial keratitis. Am J Ophthalmol. 1995;120(1):47-54.

3. Labalette P, Maurage CA, Jourdel D, Savage C, Rouland JF. [Nontuberculous mycobacterial keratitis: report of two cases causing infectious crystalline keratopathy]. J Fr Ophthalmol. 2003;26(2):175-81. French.

4. Huang SC, Soong HK, Chang JS, Liang YS. Non-tuberculous mycobacterial keratitis: a study of 22 cases. Br J Ophthalmol. 1996;80(11):962-8.

5. Freitas D, Alvarenga L, Sampaio J, Mannis M, Sato E, Sousa L, et al. An outbreak of Mycobacterium chelonae infection after LASIK. Ophthalmology. 2003;110(2):276-85.

6. Sechi LA, Zanetti S, Dupre I, Delogu G, Fadda G. Enterobacterial repetitive intergenic consensus sequences as molecular targets for typing of Mycobacterium tuberculosis strains. J Clin Microbiol. 1998;36(1):128-32.

7. Zhang Y, Rajagopalan M, Brown BA, Wallace Jr RJ. Randomly amplified polymorphic DNA PCR for comparison of Mycobacterium abscessus strains from nosocomial outbreaks. J Clin Microbiol. 1997;35(12):3132-9.

8. Alvarenga L, Freitas D, Hofling-Lima AL, Belfort R Jr, Sampaio J, Sousa L, et al. Infectious post LASIK crystalline keratopathy caused by nontuberculous mycobacteria. Cornea. 2002;21(4):426-9. 